九州大学学術情報リポジトリ

Kyushu University Institutional Repository

\title{
Simple Analysis Method of Hexavalent Chromium in Soil Using a Portable Device
}

TAKAHASHI, Yukar i

Faculty of Contemporary Society, Toyama University of International Studies

KAWAGO, Umi

Noto Marine Laboratory, Institute of Nature and Environmental Technology, Division of Marine Environmental Studies, Kanazawa University

SHIMASAKI, Yohe i

Department of Bioresource Sciences, Faculty of Agriculture, Kyushu University

OSHIMA, Yuj i

他

https://doi.org/10.5109/4363551

出版情報：九州大学大学院農学研究院紀要. 66 (1)，pp.53-56，2021-03-01. Faculty of Agriculture， Kyushu University

バージョン :

権利関係 : 


\title{
Simple Analysis Method of Hexavalent Chromium in Soil Using a Portable Device
}

\author{
Yukari TAKAHASHI ${ }^{1}$, Umi KAWAGO ${ }^{2}$, Yohei SHIMASAKI, Yuji OSHIMA \\ and Nobuo SUZUKI ${ }^{2 *}$
}

\author{
Laboratory of Marine Environmental Science, Faculty of Agriculture, \\ Kyushu University, Fukuoka 819-0395, Japan \\ (Received October 28, 2020 and accepted November 4, 2020)
}

\begin{abstract}
A simple method for the analysis of hexavalent chromium in soil was examined. We examined an analytical method that combines diphenylcarbazide absorptiometry, which has the advantages of simplicity and speed, and a detection method using a portable spectrophotometer with good portability, and investigated its validity. Good linearity was obtained. The recovery of $\mathrm{Cr}(\mathrm{VI})$ was $92.5 \pm 2.3 \%$, and the determination limit was about $30 \mu \mathrm{g} / \mathrm{g}$-soil. Soil contamination is often unevenly distributed in portions of contaminated areas, so many samples need to be analyzed to find contaminated sites. Therefore, the ability to analyze hexavalent chromium levels at low cost using a portable device may also apply for soil analysis in developing countries.
\end{abstract}

Key words: hexavalent chromium, soil, analysis, portable device

\section{INTRODUCTION}

Hexavalent chromium $\{\mathrm{Cr}(\mathrm{VI})\}$ compounds, which include chromium acid, sodium dichromate, and potassium dichromate, are major soil contaminants (for a review see, Ministry of Environment, 2012). Cr(VI) compounds are used as raw materials for pigments, abrasives, oxidizing agents, plating and metal surface treatments, leather tanning, and so on (for a review see, Fujiwara, 2002). Once Cr(VI) is released into the environment from factories, it may cause surface and ground water contamination and soil contamination. There have been many reports of soil and groundwater contamination due to $\mathrm{Cr}(\mathrm{VI})$ emission, including reports describing Cr(VI) emission from tanning factories in India and other South Asian countries (for reviews see, Debajyoti et. al., 2015 and Shams et. al., 2009).

Cr(VI) has been shown to damage the kidneys, liver and central nervous system, and to cause a range of conditions including dermatitis and nasal septum perforation (for a review see, Paul et. al., 2002). The carcinogenicity of hexavalent chromium has also been pointed out (for a review see, Jones, 1990).

For these reasons, Cr(VI) was designated as a specified hazardous substance in the Soil Contamination Countermeasures Act, Government of Japan on 29 May 2002. The elution test (for a review see, Ministry of the Environment 1991 and Ministry of the Environment 2003a) and content test (for a review see, Ministry of the

\footnotetext{
1 Faculty of Contemporary Society, Toyama University of International Studies, Higashikuromaki, Toyama 930-1292, Japan

2 Noto Marine Laboratory, Institute of Nature and Environmental Technology, Division of Marine Environmental Studies, Kanazawa University, Noto-cho, Ishikawa 927-0553, Japan

* Corresponding author (E-mail: nobuos@staff.kanazawa-u. ac.jp)
}

Environment 2003b) are commonly used to investigate the contamination of soil with $\mathrm{Cr}(\mathrm{VI})$.

Various methods, including diphenylcarbazide absorptiometry, frame atomic absorption method, inductively coupled plasma (ICP) emission spectroscopy, and liquid chromatography-ICP mass spectrometry, are generally used to detect Cr (VI) (for reviews see, Japanese Standard Association, 2016, Lesniewska et. al., 2019, Shigeta et. al., 2018 and Tatsumi et. al. 2013).

On the other hand, as soil contamination is not uniform, it is necessary to analyze a large number of samples in order to identify contaminated areas. If a method were available for easy analysis of soil samples on-site, Cr(VI) contamination could be detected more efficiently.

In this study, we examined an analytical method that combines diphenylcarbazide absorptiometry, which has the advantages of simplicity and speed, and a detection method using a portable spectrophotometer with good portability, and investigated its validity.

\section{MATERIALS AND METHODS}

\section{Soil}

The soil samples used in these experiments were collected in Toyama city, Toyama prefecture. The collected soils were sealed and stored at room temperature away from direct sunlight. After air-drying, small and medium-sized gravel, wood chips, etc. were removed, and then the soils were passed through a $2 \mathrm{~mm}$ mesh sieve before use in the tests.

\section{Reagents}

A standard stock solution was prepared by dissolving potassium chromate $\left(\mathrm{K}_{2} \mathrm{CrO}_{4}\right.$; Wako Chemical Industry, Osaka, Japan) in distilled water. Standard solutions were then prepared by appropriately diluting this standard stock solution. Commercial pretreatment reagents $\left(\mathrm{Cr}^{6^{+}}-\mathrm{RB}\right.$; Kyoritsu Chemical-Check Lab., 
Corp., Tokyo, Japan) were used for soil pretreatment and commercial analytical kits (WAK- $\mathrm{Cr}^{6+} ; \mathrm{Kyoritsu}$ Chemical-Check Lab., Corp.) were used for coloring by the diphenylcarbazide method.

Carbonate-bicarbonate buffer solution $(0.01 \mathrm{~mol} / \mathrm{L})$ was prepared by mixing sodium carbonate (Wako Chemical Industry) and sodium hydrogen carbonate (Wako Chemical Industry). This solution was used to extract Cr(VI) from soil.

\section{Apparatus}

A portable spectrophotometer (Spectroquant Move 100; Merck KGaA, Darmstadt, Germany) was used to detect the $\mathrm{Cr}(\mathrm{VI})$ colored with diphenylcarbazide. A tabletop spectrophotometer (ASV11D; AS ONE Corp., Osaka, Japan) was used to check the accuracy of the portable spectrophotometer. The absorbance was measured at a measurement wavelength of $530 \mathrm{~nm}$ for both devices.

\section{Recovery test}

A batch experiment was conducted with polyethylene bottles. The soil sample was weighed (the dry weight was estimated from moisture content), and then $50 \mu \mathrm{g}$ of $\mathrm{Cr}(\mathrm{VI})$ was added and the soil was air-dried. Next, $50 \mathrm{~mL}$ of carbonate-bicarbonate buffer solution was added to the soil and Cr(VI) was extracted by shaking for 2 hours using a rotary shaker (200 rpm). After extraction, $3.0 \mathrm{~mL}$ of the extract solution was collected and centrifuged, and the supernatants were filtrated. A $1.5 \mathrm{~mL}$ aliquot of the filtrated sample was supplemented with commercial pretreatment reagent and then the reagent from commercial analytical kits. The absorbance was measured at a measurement wavelength of $530 \mathrm{~nm}$ and the amount of recovery was calculated from the difference between the samples supplemented with $\mathrm{Cr}(\mathrm{VI})$ and those without $\mathrm{Cr}(\mathrm{VI})$.

\section{RESULTS and DISCUSSION}

\section{Reaction time}

Figure 1 shows the relationship between the reaction time and the absorbance using a chromium standard solution. The absorbance at a reaction time of 2 minutes was 0.296 , suggesting that the reaction had not pro-

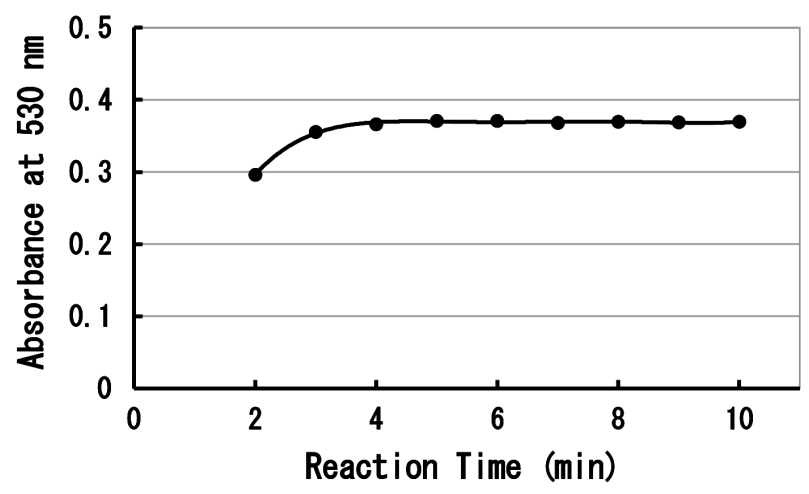

Fig. 1. Results of the reaction time study The results are expressed as the mean of duplicate data. gressed sufficiently. On the other hand, when the reaction time was 4 minutes or more, the absorbance was in the range of 0.366 to 0.371 . Therefore, we concluded that the reaction time in these experiments was 4 minutes.

\section{Calibration curve and variability}

Figure 2 shows the results of portable spectrophotometric measurements of the absorbance of the $\mathrm{Cr}(\mathrm{VI})$ standard solution in the concentration range of 0.03125 $\mathrm{mg} / \mathrm{L}$ to $0.50 \mathrm{mg} / \mathrm{L}$. Good linearity was observed between the $\mathrm{Cr}$ (VI) concentration and absorbance, at least within this concentration range. These measurements were repeated on another day (Fig. 2), and similar linearity between the Cr (VI) concentration and absorbance in this concentration range was observed. The slope of the calibration curve for the first measurement was 1.13-fold greater than the slope for the second measurement. These results suggested that the slight tilt fluctuations could be corrected by measuring the concentration and absorbance of the standard solution and blank sample on each measurement day.

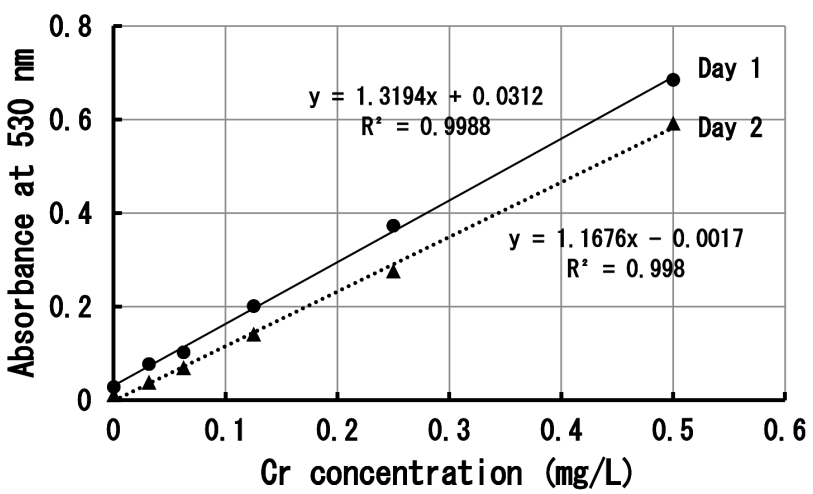

Fig. 2. Daily variation of the calibration curve.

\section{Reproducibility}

In order to examine the reproducibility of this method, a Cr(VI) standard solution at a concentration of $0.03125 \mathrm{mg} / \mathrm{L}$ was analyzed 5 times using a portable spectrophotometer and tabletop spectrophotometer, respectively. Then, the average absorbance, standard deviation, and relative standard deviation (RSD) of each data were calculated. These results are shown in Table 1. The RSD from the repeated measurements of the low concentration $(0.03125 \mathrm{mg} / \mathrm{L})$ standard solution was $12 \%$, and this was not different from the RSD from the measurements using the desktop-type spectrophotometer. Similarly, a chromium standard solution having a concentration of $0.25 \mathrm{mg} / \mathrm{L}$ was also measured. These results are also shown in Table 1 . The RSD from the analysis of the $\mathrm{Cr}(\mathrm{VI})$ standard solution at a concentration of $0.25 \mathrm{mg} / \mathrm{L}$ was $6.7 \%$ for the portable spectrophotometer and $2.6 \%$ for the desktop spectrophotometer. The variability using the desktop-type spectrophotometer was smaller than that using the portable-type spectrophotometer, but the variability using the portabletype device was also acceptable for the analysis. When 
Table 1. Comparison of the reproducibility of $\mathrm{Cr}(\mathrm{VI})$ detection

\begin{tabular}{cccccc}
\hline & $\operatorname{Cr}(\mathrm{VI}) \quad(0.03125 \mathrm{mg} / \mathrm{L})$ & \multicolumn{3}{c}{$\operatorname{Cr}(\mathrm{VI}) \quad(0.25 \mathrm{mg} / \mathrm{L})$} \\
\hline \multirow{2}{*}{ No. } & $\begin{array}{l}\text { Portable } \\
\text { spectrophotometer }\end{array}$ & $\begin{array}{l}\text { Tabletop } \\
\text { spectrophotometer }\end{array}$ & No. & $\begin{array}{l}\text { Portable } \\
\text { spectrophotometer }\end{array}$ & $\begin{array}{l}\text { Tabletop } \\
\text { spectrophotometer }\end{array}$ \\
\hline \hline 1 & 0.074 & 0.019 & 1 & 0.319 & 0.160 \\
\hline 2 & 0.079 & 0.020 & 2 & 0.367 & 0.167 \\
\hline 3 & 0.065 & 0.020 & 3 & 0.361 & 0.166 \\
\hline 4 & 0.059 & 0.023 & 4 & 0.370 & 0.159 \\
\hline 5 & 0.076 & 0.025 & 5 & 0.329 & 0.158 \\
\hline \hline Average & 0.071 & 0.0214 & Average & 0.349 & 0.162 \\
\hline $\begin{array}{c}\text { Standard } \\
\text { Deviation }\end{array}$ & 0.0083 & 0.0025 & $\begin{array}{c}\text { Standard } \\
\text { Deviation }\end{array}$ & 0.0235 & 0.0042 \\
\hline RSD* & $12 \%$ & $12 \%$ & RSD* & $6.7 \%$ & $2.6 \%$ \\
\hline
\end{tabular}

*RSD: Relative Standard Deviation

measuring low-concentration solutions, the variability tended to be greater than when measuring high-concentration solutions. When analyzing low-concentration samples, the RSD is generally large due to the influence of the background. However, in this case the variation was relatively small and the analysis could be performed accurately.

\section{Recovery and determination limit}

Table 2 shows the recovery rate obtained by recovery test. The average recovery of Cr (VI) from soil was $92.5 \pm 2.3 \%$, this recovery rate was considered satisfactory and the variability was found to be small. The results indicated that $\mathrm{Cr}(\mathrm{VI})$ can be extracted by $0.01 \mathrm{~mol} / \mathrm{L}$ carbonate-bicarbonate buffer solution and can be detected using packed reagents, at least in the soil samples tested here. However, there are many types of soil in the world, so many types of soil should be tested in the near future.

Assuming that the lower limit of quantification is 10 times the absorbance measurement result of soil samples not contaminated with chromium, the determination limit was estimated to be about $30 \mu \mathrm{g} / \mathrm{g}$-soil.

Soil contamination is often unevenly distributed in portions of contaminated areas, so many samples need to be analyzed to find contaminated sites. Therefore, being able to analyze on-site at low cost is useful for identifying contaminated sites. In addition, the ability to

Table 2. Recovery of $\mathrm{Cr}(\mathrm{VI})$

\begin{tabular}{cc}
\hline No. & Recovery \\
\hline \hline 1 & $92.4 \%$ \\
\hline 2 & $90.3 \%$ \\
\hline 3 & $96.0 \%$ \\
\hline 4 & $92.0 \%$ \\
\hline 5 & $91.7 \%$ \\
\hline \hline Average & $92.5 \%$ \\
\hline RSD* & $2.3 \%$ \\
\hline
\end{tabular}

*RSD: Relative Standard Deviation analyze soil samples at low cost using a portable device would be of great benefit in developing countries.

To establish a system that can realize these goals, we tested an analytical method combining a portable spectrophotometer and commercially available packed reagent, and showed that it easily measured Cr(VI) in soil. Based on the results of the reproducibility, the recovery rate test and the daily variability, the validity of the analysis method was confirmed. This method can be applied for the identification of $\mathrm{Cr}(\mathrm{VI})$ contamination in soil.

\section{AUTHOR CONTRIBUTIONS}

Y. Takahashi and U. Kawago designed the study. U. Kawago performed experiments and analyzed the data. Y. Takahashi wrote the paper. N. Suzuki, Y. Oshima and Y. Shimasaki supervised the work. All authors assisted in editing of the manuscript and approved the final version.

\section{REFERENCES}

De., B. Choudhary, T. Gupta and M. T. Jose 2015 Spatial distribution and the extent of heavy metal and hexavalent chromium pollution in agricultural soils from Jajmau, India. Environ. Earth Sci., 73: 3565-3577

Environmental Management Bureau of Ministry of the Environment 2012 Monitoring results of groundwater quality in FY 2010 Ministry of the Environment (Japan)

Fujiwara, Y. 2002 Hevavalent chromium. Soil Mech. Found. Eng. 50: 41-42

Japanese Standard Association 2016 Testing methods for industrial wastewater, JIS K 0102-2016: 272-275

Jones, R. E. 1990 Hexavalent chrome: Threshold concept for carninogenicity. Biomed. Environ. Sci, 3: 20-34

Lesniewska, B. and B. G. Zylkiewicz 2019 Speciation of chromium in alkaline soil extracts by an ion-pair reversed phase HPLC-ICP MS method. Molecules 24: 1172

Ministry of the Environment 1991 Matters to determine the measurement method for soil elution amount survey. Ministry of the Environment Notification No.46. (in Japanese)

Ministry of the Environment 2003a Matters to determine the measurement method for soil elution survey. Ministry of the Environment Notification No.18. (in Japanese)

Ministry of the Environment 2003b Matters to determine the measurement method for soil content survey. Ministry of the Environment Notification No. 19. (in Japanese)

Shams, K. M., G. Tichy, M. Sager, T. Peer, A. Bashar and M. Jozic 
2009 Soil Contamination From Tannery Wastes with Emphasis on the Fate and Distribution of Tri- and Hexavalent Chromium. Water Air Soil Pollut., 199: 123-137

Shigeta, K., A. Fujita, T. Nakazato and H. Tao 2018 A robust method for the determination of $\mathrm{Cr}(\mathrm{VI})$ and $\mathrm{Cr}(\mathrm{III})$ in industrial wastewaters by liquid chromatography-inductively coupled plasma mass spectrometry combined with a chelating pretreatment with 2,6-pyridinedicarboxylic acid. Anal Sci 34: 925-932

Tatsumi, M., S. Ozaki and E. Nakamura 2013 Determination of chromium (VI) by two-channel flow injection analysis system using dilute acetone-based diphenylcarbazide solution. Bunseki Kagaku 61: 31-35 